Brit. J. vener. Dis. (1963), 39, 192.

\title{
INEFFECTIVENESS OF LYSOZYME THERAPY IN EXPERIMENTAL SYPHILIS IN THE RABBIT*
}

\author{
BY \\ GEORGE R. CANNEFAX AND ALBERT W. HANSON \\ From the Venereal Disease Research Laboratory, Venereal Disease Branch, Communicable Disease Center, U.S. Public \\ Health Service, Atlanta 22, Georgia.
}

Lysozyme is a mucolytic enzyme which catalyses the depolymerization of highly polymerized mucopolysaccharides of the cell wall of certain bacteria. It is found in tears, nasal mucus, plasma, urine, leucocytes, in some moulds, in egg white, and in the latex of different plants. It is a basic, single-chain polypeptide. In consequence of its lytic properties, lysozyme has been classified as an antibiotic.

Metzger, Hardy, and Nell (1961) demonstrated that lysozyme had an accelerating effect upon the kinetics of the Treponema pallidum immobilization (TPI) reaction, and suggested that this occurred because of enzymatic removal of a non-antigenic mucopolysaccharide surface layer from the treponemes. Casciano and Costa (1960) and Costa and Casciano (1961) reported that lysozyme is effective in the treatment of early syphilis in man, but Montagnani, Montilli, and Avellino (1961), in a similar study found lysozyme to be ineffective. In view of the demonstrated effect in vitro of lysozyme on the treponeme and the difference in two reports concerning the effectiveness of lysozyme in the treatment of syphilis in man, it was deemed not only desirable but necessary that the effectiveness of lysozyme in the treatment of experimental syphilis in the rabbit should be investigated. The purpose of this report is to present the data of a limited study in which three levels of lysozyme dosage were found to be ineffective in the treatment of experimental syphilis in the rabbit.

\section{Materials and Methods}

The lysozyme used was produced by the Società Prodotti Antibiotici (SPA), Milan, Italy, and provided through the courtesy of Dr. Antonio L. Costa, University of Messina, Italy. SPA lysozyme is a sterile lyophilized chloride salt of the enzyme. The potency in enzyme units

\footnotetext{
* Received for publication May 10, 1963.
}

is not stated. However, when SPA lysozyme was compared in a turbidimetric assay with a standard lysozyme preparation having 8,000 units/mg., it was found to have an equivalent enzyme activity.

Solutions of lysozyme (30 mg./ml.) were prepared daily in sterile 0.85 per cent. sodium chloride solution and stored in the refrigerator at $6-8^{\circ} \mathrm{C}$.

Male New Zealand White rabbits weighing 7-81b. were inoculated intradermally in a single site with 1,000 virulent $T$. pallidum (Nichols strain). Sites were cleanly shaven, without abrasions, and the inoculations were made near the midline of the back near the shoulders. Six rabbits were injected to serve as test animals to assess the value of lysozmye therapy and five were inoculated to serve as untreated controls. All animals were dark-field positive on the 16th post-inoculation day and treatment was started 2 days later.

Three dosage schedules were employed which were relative to the dosage employed by Costa and Casciano (1961) and by Montagnani, and others (1961), i.e. 150 $\mathrm{mg}$./patient/day. Assuming that the patients averaged $150 \mathrm{lb}$. the dosage level was in the range of $1 \mathrm{mg}$./lb./day. The dosage levels used in this study were 2,4 , and $8 \mathrm{mg}$./lb./day because a preliminary study with lysozyme indicated that the $1 \mathrm{mg}$./lb./day was not effective in the treatment of experimental syphilis in the rabbit. One-half of the daily dosage was given by intramuscular injection at 8- and 16-hour intervals for convenience in relation to the normal working day. Duration of treatment was 21 days.

Serologic tests for syphilis were performed according to the serologic techniques set forth in the "Manual of Serologic Tests for Syphilis” (1959 revision).

\section{Test Animals}

Two rabbits (91 and 96 ) received lysozyme therapy at a level of $2 \mathrm{mg}$./lb./day. - The initial lesion of rabbit 91 remained dark-field positive for the duration of observation (50 days). Number 91 developed dark-field positive secondary lesions 21 days 192 
after starting therapy and these remained dark-field positive for 19 days. Number 96 developed secondary lesions 26 days after the initiation of therapy and remained dark-field positive for 12 days.

Two rabbits (95 and 112) were treated with lysozyme at a level of $4 \mathrm{mg}$./lb./day.-Animal 95 remained darkfield positive throughout the 50-day observation period and secondary lesions which developed 20 days after starting therapy remained dark-field positive for 25 days.

The course of the disease in rabbit 112 was unusual. 13 days after beginning therapy the initial lesion became dark-field negative. However, 20 days following the first dark-field negative observation of the primary lesion a dark-field positive lesion appeared at the site of the previously healed primary lesion (monorecidive) and this remained dark-field positive for the duration of observation (17 days). During this period no other lesions developed.

Two rabbits (115 and 116) received lysozyme therapy at a level of $8 \mathrm{mg}$./lb./day. - The primary lesions of both these animals became dark-field negative 19 days after starting lysozyme therapy and no secondary lesions developed during the observation period (50 days).

\section{Control Animals}

Rabbit 94 became dark-field negative 16 days after the first dark-field positive observation on the initial lesion. This animal did not develop secondary lesions during the observation period (50 days).

The dark-field positive primary lesions of the other control animals $(90,98,111,117)$ remained dark-field positive throughout the observation period ( 50 days) without the development of secondary lesions.
The number of days which elapsed in all these experiments between starting therapy and observation of a dark-field negative primary lesion, darkfield positive secondary lesion, or dark-field negative secondary lesion is shown in the Table.

\section{Results of Serological Testing}

The results of the VDRL slide test, the $1 / 5$ volume Kolmer technique with cardiolipin and Reiter protein antigens, and the Treponema pallidum immobilization (TPI) test are shown in the Table. The ranges and variations of reactivity observed with all the animals with the titre tests and with the TPI test is what one usually observes in untreated syphilis in the rabbit. It is apparent that there is no difference in the reactivity range of any given test when the treated and untreated animals are compared.

\section{Discussion}

Before the observations reported here we treated two rabbits with crystalline lysozyme of American manufacture and two rabbits with lysozyme chloride which we prepared from crystalline lysozyme. The rabbits had dark-field positive primary lesions when treatment was started and the dosage was $1 \mathrm{mg}$./lb./ day for 20 days. All the animals remained dark-field positive throughout the observation period with either primary or secondary lesions, and then all developed positive serological tests for syphilis, the TPI test included. An untreated control group of four rabbits followed the same clinical and serological course. These observations were unlike those of Costa and Casciano (1961), who reported the disappearance of treponemes from lesions after 1 to 4 days of lysozyme therapy of early syphilis in man, followed

TABLE

RESULTS OF DARK-FIELD EXAMINATIONS AND SEROLOGICAL TESTS

\begin{tabular}{|c|c|c|c|c|c|c|c|c|}
\hline \multirow{3}{*}{$\begin{array}{c}\text { Dosage } \\
\text { (mg./lb./day) }\end{array}$} & \multirow{3}{*}{$\begin{array}{c}\text { Animal } \\
\text { Number }\end{array}$} & \multicolumn{3}{|c|}{$\begin{array}{l}\text { No. of Days elapsing before } \\
\text { Observation by Dark-field }\end{array}$} & \multicolumn{4}{|c|}{ Serological Tests 50 days after starting Therapy } \\
\hline & & \multirow{2}{*}{$\begin{array}{l}\text { Negative } \\
\text { Primary } \\
\text { Lesion }\end{array}$} & \multirow{2}{*}{$\begin{array}{l}\text { Positive } \\
\text { Secondary } \\
\text { Lesion }\end{array}$} & \multirow{2}{*}{$\begin{array}{l}\text { Negative } \\
\text { Secondary } \\
\text { Lesion }\end{array}$} & \multirow{2}{*}{$\begin{array}{l}\text { VDRL } \\
\text { Slide } \\
\text { Test }\end{array}$} & \multicolumn{2}{|c|}{$1 / 5$ Vol. Kolmer } & \multirow{2}{*}{$\begin{array}{l}\text { Treponema pallidum } \\
\text { Immobilization } \\
\text { test }\end{array}$} \\
\hline & & & & & & Cardiolipin & Reiter Protein & \\
\hline $\begin{array}{l}2 \\
4 \\
8\end{array}$ & $\begin{array}{r}91 \\
96 \\
95 \\
112 \\
115 \\
116\end{array}$ & $\begin{aligned}>50^{*} \\
38 \\
>50 \\
13 \\
19 \\
19\end{aligned}$ & 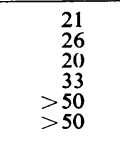 & $\begin{array}{r}40 \\
38 \\
45 \\
>50 \\
- \\
\end{array}$ & $\begin{array}{c}16 \dagger \\
2 \\
16 \\
4 \\
4 \\
8\end{array}$ & $\begin{array}{r}32 \\
8 \\
32 \\
4 \\
8 \\
8\end{array}$ & $\begin{array}{r}16 \\
8 \\
32 \\
4 \\
32 \\
16\end{array}$ & $\begin{array}{l}\text { Reactive } \\
\text { Non-reactive } \\
\text { Reactive } \\
\text { Non-reactive } \\
\text { Weakly Reactive } \\
\text { Weakly Reactive }\end{array}$ \\
\hline $\begin{array}{l}\text { Untreated } \\
\text { Controls }\end{array}$ & $\begin{array}{r}90 \\
94 \\
98 \\
111 \\
117\end{array}$ & $\begin{array}{r}>50 \\
16 \\
>50 \\
>50 \\
>50\end{array}$ & $\begin{array}{l}>50 \\
>50 \\
>50 \\
>50 \\
>50\end{array}$ & $\begin{array}{l}E \\
z \\
-\end{array}$ & $\begin{array}{r}16 \\
2 \\
16 \\
2 \\
4\end{array}$ & $\begin{array}{r}64 \\
8 \\
64 \\
4 \\
16\end{array}$ & $\begin{array}{r}16 \\
4 \\
16 \\
2 \\
8\end{array}$ & $\begin{array}{l}\text { Reactive } \\
\text { Reactive } \\
\text { Reactive } \\
\text { Weakly Reactive } \\
\text { Weakly Reactive }\end{array}$ \\
\hline
\end{tabular}

* Observations ended 50 days after starting therapy.

+ Titre expressed as the reciprocal of the highest reactive dilution. 
by rapid healing of the lesions and disappearance of serological reactivity.

Attempting to reconcile these differences in therapeutic response we postulated that rabbits may require a higher dosage, or that the observed differences may be due to fundamental differences in lysozyme of American and Italian manufacture. Dr. Costa kindly sent us a free supply of SPA lysozyme, the product used in the successful treatment of early syphilis in man reported by Costa and Casciano (1961).

Using this SPA lysozyme at approximately two, four, and eight times the dosage level of Costa and Casciano (1961), we found no essential differences in the clinical course of the infection or in the development of serological activity, in the animals treated with lysozyme and the untreated control animals. We can give no reason for the difference between the excellent clinical and serological response in man reported by Costa and Casciano (1961) and the ineffectiveness of lysozyme in the treatment of experimental syphilis in rabbits found during this study.

The only other report known to us of the treatment of early syphilis in man with lysozyme in that of Montagnani and others (1961). These investigators reported clinical and serological observations of nine dark-field positive cases of primary syphilis and one case of secondary syphilis treated with $75 \mathrm{mg}$. lysozyme every 12 hours for 20 to 31 days. They observed that the serological tests, including the TPI test, increased in reactivity during the period of lysozyme therapy and that the administration of lysozyme did not hasten the regression of lesions. Three cases developed secondary manifestations (syphiloderma) while under lysozyme therapy. These authors felt that the observed regression of lesions might have come about spontaneously. It is our impression, also, that the regression of the lesions in our study may have come about spontaneously when one compares the dark-field results of the treated and the untreated control rabbits.

It is recognized that the number of animals in this study is too few to permit a critical statistical conclusion and that this is a valid criticism of the study. Nevertheless, the results suggest that lysozyme is of no value in the treatment of experimental syphilis in the rabbit even when given in a dosage approximately eight times greater than that reported as effective in treating early syphilis in man. Certainly, lysozyme in the concentrations employed in this study does not cause the rapid disappearance of organisms from the lesions which is observed with penicillin and other effective antibiotics and chemotherapeutic agents.

\section{Summary}

Rabbits experimentally infected with syphilis were treated with lysozyme chloride at dosages of 2,4 , and $8 \mathrm{mg}$./lb./day for 21 days. The treated animals gave the same clinical and serological responses, during and after treatment, as an untreated control group. This study therefore suggests that lysozyme, at the dosage levels used, is ineffective in the treatment of experimental syphilis in the rabbit.

We wish to express our thanks to Mrs. Dorothy $\mathbf{L}$. Douglas for technical assistance in the preparation and dark-field examination of material from the lesions and to the members of the Serologic Testing Unit of the Venereal Disease Research Laboratory who performed the serological tests.

\section{REFERENCES}

Casciano, A., and Costa, A. L. (1960). Dermatologia 11,155 .

Costa, A. L., and Casciano, A. (1961). "Proceedings of the II International Symposium on the Lysozyme of Fleming (Milan)", April 7-9, 1961, p. 23.

"Manual of Serologic Tests for Syphilis" (1959). Public Health Service, Publication No. 411 (Revised 1959). U.S. Government Printing Office, Washington, D.C.

Metzger, M., Hardy, P. H., Jr., and Nell, E. E. (1961). Amer.J. Hyg., 73, 236.

Montagnani, A., Montilli, G., and Avellino, M. (1961). Dermatologia, 12, 31 .

\section{Inefficacité de la lysozyme contre la syphilis expérimentale \\ RÉSUMÉ}

Des lapins atteints de syphilis expérimentale reçurent 4,8 et $16 \mathrm{mg}$. de chlorure de lysozyme par jour, et pendant 3 semaines. Il n'y eut aucune différence entre les animaux traités et une série de témoins non-traités.

Ces résultats indiquent que la lysozyme, dans les doses employées, est inefficace contre la syphilis expérimentale chez le lapin. 